CLINICAL STUDY

\title{
Expressions of miRNAs in papillary thyroid carcinoma and their associations with the BRAF ${ }^{\mathrm{V} 600 \mathrm{E}}$ mutation
}

\author{
Yongbo Huang ${ }^{1,2,3, *}$, Denghui Liao ${ }^{1,4, *}$, Lingxiao Pan ${ }^{5, *}$, Runyi $\mathrm{Ye}^{1}$, Xiaoxi $\mathrm{Li}^{1}$, Shenming Wang ${ }^{1}$, \\ Caisheng $\mathrm{Ye}^{1}$ and Liuhua Chen ${ }^{1,6}$ \\ ${ }^{1}$ Department of Vascular and Thyroid Surgery, The First Affiliated Hospital, Sun Yat-Sen University, No. 58, Zhongshan Road II, Guangzhou, Guangdong \\ 510080, China, ${ }^{2}$ Department of Microbiology, Zhongshan School of Medicine and ${ }^{3}$ Key Laboratory of Tropical Disease Control, Ministry of Education, Sun \\ Yat-Sen University, Guangzhou, Guangdong 510080, China, ${ }^{4}$ Department of Breast and Thyroid Surgery, Chongqing Hospital of Traditional Chinese \\ Medicine, Chongqing 400021, China, ${ }^{5}$ Department of Breast Surgery, The First Affiliated Hospital of Guangzhou Medical College, Guangzhou, Guangdong \\ 510120, China and ${ }^{6}$ Department of Minimally Invasive Surgery, The First Affiliated Hospital, Sun Yat-Sen University, No. 58, Zhongshan Road II, \\ Guangzhou, Guangdong 510080, China
}

(Correspondence should be addressed to C Ye; Email: yecaisheng@sina.com; LChen; Email: chlh22@163.com)

*(Y Huang, D Liao and L Pan contributed equally to this work)

\begin{abstract}
Objective: Alterations in microRNA (miRNA) expression have been described in thyroid tumors, suggesting a role for miRNAs in thyroid carcinogenesis. $B R A F^{\mathrm{V} 600 \mathrm{E}}$ is the most frequently identified genetic alteration in papillary thyroid carcinoma (PTC). We investigated the link between BRAF $F^{V 600}$ status and the expression of miRNAs in PTC and analyzed the associations of these factors with clinicopathological characteristics.

Design and methods: Prospective study of patients who underwent thyroid surgery between October 8, 2008 and November 1, 2010. BRAF ${ }^{V 600 \mathrm{E}}$ status was determined by mutant allele-specific amplification PCR and direct sequencing of exon 15 of the BRAF gene in 69 PTC tissues and 69 respective paracancerous normal thyroid tissues. Initially, miRNA expression was analyzed in 12 PTC tissues and three associated paracancerous tissues using a miRNA microarray. miRNAs differentially expressed between $B R A F^{\mathrm{V} 600 \mathrm{E}}$-positive and -negative PTC tissues were then validated by real-time quantitative PCR on 69 PTC tissues and 69 paracancerous tissues. We also explored the associations between $B R A F^{\mathrm{V} 600 \mathrm{E}}$ status or differential miRNA expression and clinicopathological characteristics. Results: The mutation rate of $B R A F^{\mathrm{V} 600 \mathrm{E}}$ in PTC was $47.8 \%$. Twelve miRNAs were upregulated and six were downregulated in PTC tissues, among which miR-15a, 15a*, 34a*, 34b*, 551b, 873, 876-3p, and $1274 \mathrm{a}$ were first identified. miR-21* and 203 were significantly dysregulated $(P<0.05)$ in PTC tissues with $B R A F^{\mathrm{V} 600 \mathrm{E}}$. Additionally, there were significant associations $(P<0.05)$ between $B R A F^{V 600 E}$ and a higher tumor-node-metastasis staging (III/IV), and between miR-21* overexpression and lymph node metastasis.

Conclusions: We identified two miRNAs that are differentially expressed in PTC tissues with BRAF $F^{\mathrm{V} 600 \mathrm{E}}$ and revealed their associations with clinicopathological features. These findings may lead to the development of a potential diagnostic biomarker or prognostic indicator of PTC.
\end{abstract}

European Journal of Endocrinology 168 675-681

\section{Introduction}

Thyroid carcinoma is one of the most common endocrine malignancies, accounting for $\sim 1 \%$ of all newly diagnosed cancers (1). It consists of four major histological types - papillary thyroid carcinoma (PTC), follicular thyroid carcinoma, medullary thyroid carcinoma, and anaplastic thyroid carcinoma - of which PTC accounts for more than $80 \%$ (2). The biological behavior and growth patterns of PTC are variable: most have a low potential for malignancy and a favorable prognosis, while others present with clinicopathological characteristics associated with a poor prognosis; these characteristics include an older onset age, a larger tumor diameter, extrathyroidal invasion, distant metastases, and aggressive histological variants $(3,4)$. Surgery (sometimes with adjuvant radiotherapy) is still the most effective approach for patients with PTC.

Previous studies $(1,5)$ have demonstrated genetic alterations in PTC: RET gene rearrangements (referred to as RET/PTC), NTRK1 gene rearrangements (referred to as TRK), and RAS or BRAF gene mutations, which are collectively involved in the RET/PTC (TRK)-RASBRAF-MEK-MAPK signaling pathway. V600E in BRAF, a thymine-to-adenine transversion at nucleotide 1799 , is a hot spot for mutations in patients with PTC. It affects exon 15 of the BRAF gene and is present in $29-83 \%$ of 
PTC cases $(6,7,8,9)$. Nucera et al. (10) revealed that $B R A F^{\mathrm{V} 600 \mathrm{E}}$ is required to maintain and promote thyroid cancer progression. Some other studies $(8,11$, $12,13,14)$ have indicated that $B R A F^{\mathrm{V} 600 \mathrm{E}}$ is associated with an increased incidence of poor clinicopathological parameters in PTC.

MicroRNAs (miRNAs), short RNAs that are usually 21-25 nucleotides in length and are generated from single-stranded miRNA gene transcripts, represent a recently identified class of endogenous noncoding RNAs. Their regulatory influence is mediated by their interactions with a protein complex called the RNA-induced silencing complex, which delivers them to their mRNA targets (15). Previous studies $(16,17,18,19)$ have demonstrated that miRNAs play a role not only in individual growth and development but also in regulating the expression of well-known oncogenes and tumor suppressor genes, and increasingly, dysregulated miRNAs have been identified in various malignancies. Recently, using miRNA microarrays and miRNA real-time quantitative PCR (qPCR), several studies $(18,19,20,21,22,23,24,25,26)$ have reported dysregulated miRNAs (such as miR-7, 21, 30, 31, 34a, 144, 146, 146b, 155, 181b, 187, 200, 200b, 221, and 222) in PTC, suggesting that these are promising targets for studying the genesis and development of PTC.

The association between $B R A F^{\mathrm{V} 600 \mathrm{E}}$ status and miRNA expression in PTC has not been thoroughly examined. Cahill et al. (27) and Nikiforova et al. (18) showed dysregulated miRNAs (miR-127, 130a, 141, 144, 146b, 155, 187, 200a, 200b, 221, and 222) in thyroid-derived cell lines and tissues with $B R A F^{\mathrm{V} 600 \mathrm{E}}$ respectively. Additionally, resulting from the rapid development of miRNA microarray, more and more human miRNAs have been identified. In this study, we i) compared miRNA expression between PTC tissues and paracancerous normal thyroid tissues using an up-to-date miRNA microarray and determined the differentially expressed miRNA in PTC tissues with $B R A F^{\mathrm{V} 600 \mathrm{E}}$ and ii) explored the associations between $B R A F^{\mathrm{V} 600 \mathrm{E}}$ status or differential miRNA expression and the clinicopathological characteristics of PTC.

\section{Materials and methods}

This study complies with the Declaration of Helsinki and was approved by the Local Ethics Committee. Informed consent was obtained from each subject or his/her guardian.

\section{Selection of cases and controls}

The current study was conducted on patients of Asian descent who had undergone thyroid surgery between October 8, 2008 and November 1, 2010. All patients were from southeast China and were admitted to the
Thyroid Department of The First Affiliated Hospital of Sun Yat-Sen University. Lesions and paracancerous thyroid tissues (the latter ones were resected from the margin of the post-resection samples and confirmed by both naked eye and hematoxylin and eosin staining to contain no apparent abnormal tissues) were successfully obtained from each of 69 patients with PTC (confirmed by hematoxylin and eosin staining, according to the widely accepted histological diagnostic criteria (28)). All the tissues were collected from surgically resected tissues and stored immediately at $-80{ }^{\circ} \mathrm{C}$ until analysis. The 69 patients (male: female $=1: 4.3$ ) were aged 14-75 years (median, 41 years; interquartile range, 23 years); 59 had classical PTC while the other 10 had the follicular variant of PTC. The tumor size was $2.48 \pm 1.31 \mathrm{~cm}$ (mean \pm s.D.); 31 cases $(44.9 \%)$ were solitary lesions, 36 cases (52.2\%) presented with lymph node metastasis, 25 cases $(36.2 \%)$ presented with extrathyroidal invasion, and 48 cases $(69.6 \%)$ were tumor-node-metastasis (TNM) staging (29) I/II.

\section{RNA and DNA extraction}

Genomic DNA and RNA were extracted from frozen specimens by standard techniques. Total RNA and DNA were extracted using TRIzol reagents (Invitrogen) and a TIANamp Genomic DNA Kit (TIANGEN, Beijing, China) respectively according to the manufacturer's instructions. The RNA and DNA quality was assessed using an Agilent 2100 Bioanalyzer (Agilent Technologies, Palo Alto, CA, USA). Only RNA samples that showed intact $18 \mathrm{~S}$ and $28 \mathrm{~S}$ ribosomal bands upon $1 \%$ agarose gel electrophoresis, and for which the A260/A280 ratio was $1.9-2.1$ and the $28 \mathrm{~S} / 18 \mathrm{~S}$ ratio was $\geq 2.0$, were deemed acceptable.

\section{Detection of BRAF ${ }^{V 600 E}$}

Mutant allele-specific amplification PCR was conducted essentially as described previously (30) to detect $B R A F^{\mathrm{V} 600 \mathrm{E}}$ mutation in the $69 \mathrm{PTC}$ tissues and the 69 paracancerous thyroid tissues. KTC-1 (a thyroid carcinoma cell line with $B R A F^{\mathrm{V} 600 \mathrm{E}}$ ) and WRO (a thyroid carcinoma cell line without $B R A F^{\mathrm{V} 600 \mathrm{E}}$ ) were used as positive and negative controls respectively. PCR products were analyzed by $2 \%$ agarose gel electrophoresis. At the same time, according to a previous study (30), exon 15 of the BRAF gene was PCR amplified from genomic DNA from the 69 PTC tissues and the 69 paracancerous thyroid tissues. PCR products were sequenced by Invitrogen. The data were analyzed using Lasergene Software (version 7.1.0; DNASTAR, Madison, WI, USA), comparing the sequences with the wild type human sequence obtained from the National Center for Biotechnology Information Gene database (http://www.ncbi.nlm.nih.gov/gene/673). PCR primers were synthesized by Invitrogen China. 


\section{miRNA microarray analysis}

miRNA expression was analyzed using a Human miRNA Microarray System Version 3 (Agilent Technologies) according to the manufacturer's instructions, with probe sets for 866 human miRNAs and 89 viral miRNAs (Sanger miRBase release 12.0). In brief, using a miRNA Complete Labeling and $\mathrm{Hyb}$ Kit (Agilent Technologies), $120 \mathrm{ng}$ total RNA was fluorescently labeled with $\mathrm{Cy} 3$ in a hybridization oven (Agilent Technologies) for $20 \mathrm{~h}$ at $55^{\circ} \mathrm{C}$, with rotation at 20 rounds per minute. Microarray hybridization, data generation, and normalization were performed by the Shanghai Biochip Corporation (Shanghai, China), following standard Agilent protocols. MeV 4.7.4 (http://www.tm4.org/mev/) was used for bioinformatic analysis and visualization of microarray data.

\section{MiRNA qPCR}

cDNA was synthesized from $10 \mathrm{ng}$ total RNA and extracted from 69 PTC tissues and 69 associated paracancerous thyroid tissues, using the TaqMan miRNA RT Kit (Applied Biosystems, Inc.). qPCR was performed to assess the expression of differentially expressed miRNAs, which were identified in $B R A F^{\mathrm{V} 600 \mathrm{E}}$ positive PTC tissues compared with $B R A F^{\mathrm{V} 600 \mathrm{E}}$-negative PTC tissues by the miRNA microarray. The expression levels of miRNAs were quantified using the miRNAspecific TaqMan miRNA Assay Kit (Applied Biosystems). According to the manufacturer's instructions, qPCR was performed on the Applied Biosystems 7500 Sequence Detection system. The expression of miRNAs was defined based on the threshold of amplification cycle number $(\mathrm{Ct})$, and the quantity of each miRNA was normalized to the expression of U6 small nuclear RNA using the equation of $2^{-\Delta C t}$ $\left(\Delta C \mathrm{t}=C \mathrm{t}_{\text {miRNA }}-C \mathrm{t}_{\mathrm{U} 6}\right)$.

\section{Statistical analysis}

The miRNA microarray data were analyzed using Significance Analysis of Microarrays (SAM) version 3.0 (http://www-stat.stanford.edu/ tibs/SAM). miRNAs were considered to be significantly differentially expressed only under the condition that the false discovery rate $=0$. Other data were analyzed using SPSS version 17.0 (SPSS, Inc.); $P<0.05$ was considered statistically significant. For the qPCR data, the Wilcoxon rank sum test was used to compare PTC tissues with and without $B R A F^{\mathrm{V} 600 \mathrm{E}}$, and the paired $t$-test was used to compare $B R A F^{\mathrm{V} 600 \mathrm{E}}$-positive PTC tissues with their associated paracancerous thyroid tissues. Moreover, the $\chi^{2}$ test (for age at diagnosis, gender, number of lesions, lymph node metastasis, TNM staging, and metastasis or recurrence) and the Wilcoxon rank sum test (for tumor size) were also used.

\section{Results}

\section{miRNA expression profiles}

Initially, miRNA expression was analyzed in 12 continuously PTC tissues plus paracancerous thyroid tissues from three out of 12 PTC patients. Figure 1 shows 12 upregulated miRNAs (fold-change $>2$ ) and six downregulated miRNAs (fold-change $<0.5$ for all except miR-30a) in PTC tissues, with statistical differences $(P<0.05)$.

\section{Detection of BRAF ${ }^{\text {V60oE }}$}

Combining mutant allele-specific amplification PCR and sequencing of $B R A F$ exon 15 , we determined that $B R A F^{\mathrm{V} 600 \mathrm{E}}$ was present in $47.8 \%(33 / 69)$ of 69 PTC tissues (Fig. 2) and was absent from all 69 paracancerous thyroid tissues.

\section{Expression of miRNAs relative to $\mathrm{BRAF}^{\mathrm{V600E}}$ status}

Two miRNAs (miR-21* and 203) were upregulated in seven $B R A F^{V 600 E}$-positive PTC tissues compared with five $B R A F^{\mathrm{V} 600 \mathrm{E}}$-negative PTC tissues (Fig. 3A), with statistical differences $(P<0.05)$. These findings were confirmed by qPCR (Fig. $3 \mathrm{~B}$ and $\mathrm{C}$ ). To further validate the association between $B R A F^{\mathrm{V} 600 \mathrm{E}}$ and these two miRNAs, the expressions of miR-21* and 203 were tested by qPCR on the other 57 PTC tissues and all 33

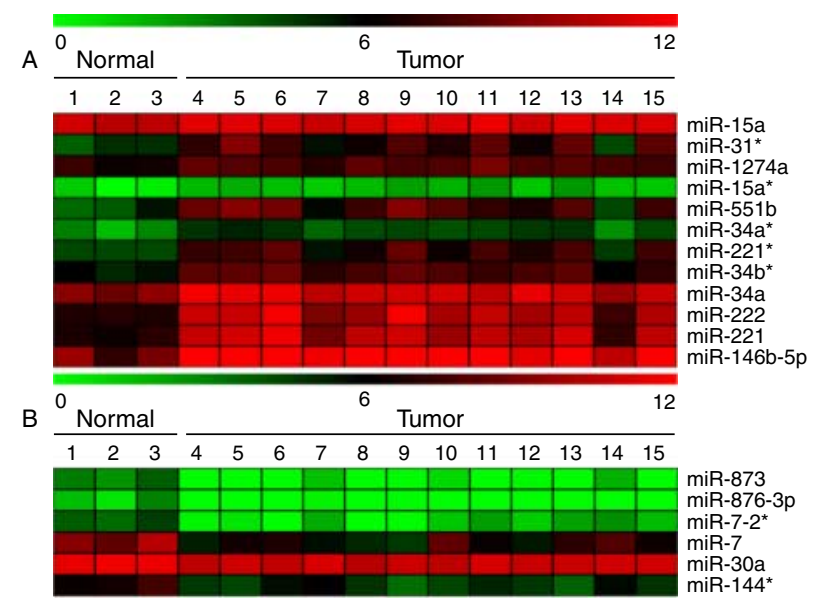

Figure 1 Heat maps of miRNA expression in papillary thyroid carcinomas and normal thyroid tissues by SAM analysis. Green bars indicate low expression and red bars indicate high expression. Nos 1-3 are normal thyroid tissues adjacent to the papillary thyroid carcinomas of Nos 7, 8, and 12 respectively. Twelve significantly upregulated $(P<0.05)$ miRNAs $(A)$ and six significantly downregulated $(P<0.05)$ miRNAs $(B)$ were found in 12 papillary thyroid carcinomas (Nos 4-15), compared with those expressed in three normal thyroid tissues (Nos 1-3). Full colour version of this figure available via http://dx.doi.org/10.1530/EJE-12-1029. 

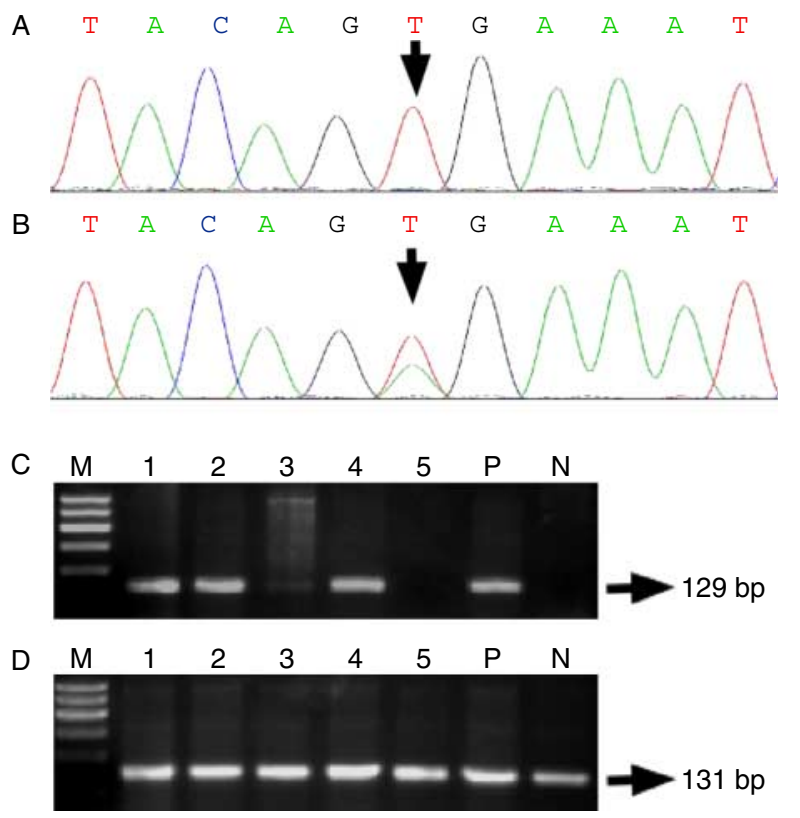

Figure 2 Detection of $B R A F^{V 600 E}$ in papillary thyroid carcinomas by DNA sequencing and mutant allele-specific amplification PCR (A) A BRAF ${ }^{V 600}$-negative DNA sample shows a single peak at nucleotide 1799 (arrow); (B) a BRAF ${ }^{\mathrm{V} 600 \mathrm{E}}$-positive (1799 T $>A$ ) DNA sample shows a double peak at nucleotide 1799 (arrow); (C) arrow shows the PCR products obtained by primers specific for mutant; (D) arrow shows the PCR products obtained by primers specific for wild type. M, marker (100-600 bp); P, positive control $\mathrm{KTC}-1$ cell line (a thyroid carcinoma cell line with $B R A F^{\mathrm{V} 600 \mathrm{E}}$ ); $\mathrm{N}$, negative control MRO cell line (a thyroid carcinoma cell line without $B R A F^{\mathrm{V} 600 \mathrm{E}}$ ). Full colour version of this figure available via http://dx.doi.org/10.1530/EJE-12-1029.

paracancerous thyroid tissues from $B R A F^{\mathrm{V} 600 \mathrm{E}}$-positive PTC patients. miR-21* and 203 were upregulated in 45 and 41 PTC tissues respectively. And both of them were significantly dysregulated $(P<0.05)$ in $B R A F^{\mathrm{V} 600 \mathrm{E}_{-}}$ positive PTC tissues compared with $B R A F^{\mathrm{V} 600 \mathrm{E}}$-negative PTC tissues or the associated paracancerous thyroid tissues, with coherence of changing trend (Fig. 4).

\section{Relationships between BRAF ${ }^{V 600 E}$ status or differential miRNA expression and the clinicopathological characteristics}

Significant associations $(P<0.05)$ were identified for the 69 PTC patients between $B R A F^{\mathrm{V} 600 \mathrm{E}}$ positivity and a higher TNM stage (III/IV), and between miR-21* over-expression and lymph node metastasis (Table 1 ). By contrast, there was no significant association $(P>0.05)$ between miR-203 expression and the clinicopathological characteristics (Table 1).

\section{Discussion}

Although PTC is the most common type of thyroid carcinoma, and also has the best prognosis, local recurrence or distant metastasis can occur $(3,4)$. Moreover, some studies $(8,11,12,13)$ have pointed out the increased incidence of poor clinicopathological features in PTC with $B R A F^{\mathrm{V} 600 \mathrm{E}}$. Owing to the great progress in the field of miRNA, it has become a hot research topic in kinds of diseases (including PTC). Limited in PTC and highlighting the paracancerous normal thyroid tissues as control group, the current study provided new insights into the following by up-to-date miRNA microarray and $B R A F^{\mathrm{V} 600 \mathrm{E}}$ detection: i) besides some previously reported $(18,19,20$, $21,22,23,24,25,26)$ miRNAs, a set of miRNAs were dysregulated in PTC; ii) the expressions of miR-21* and 203 were significantly associated $(P<0.05)$ with $B R A F^{\mathrm{V} 600 \mathrm{E}}$ status; and iii) over-expression of miR-21* was significantly associated $(P<0.05)$ with poor clinicopathological prognostic feature.

According to recent reports $(31,32,33)$, the differential expression of miRNAs in different thyroid nodules, sampled by fine-needle aspiration, may improve the preciseness of preoperative diagnosis. As early as 2005, He et al. (20) demonstrated that three miRNAs (miR-146, 221, and 222) were significantly upregulated in PTC, using a miRNA microarray. Similar studies $(18,19,21,22,23,24,25,26)$ have appeared in the later literature. Because of the rapid development of miRNA microarray technology (there are now more than 1000 identified human miRNAs), using up-to-date miRNA microarray may help to enrich the knowledge about miRNA expression in PTC. In the current study, we found 18 dysregulated miRNAs, among which miR-15a, 15a*, 34a*, 34b*, 551b, 873, 876-3p, and 1274 a were first found in PTC.

$B R A F^{\mathrm{V} 600 \mathrm{E}}$, formerly named $B R A F^{\mathrm{V} 599 \mathrm{E}}$, was first discovered by Davies et al. (34) in malignant melanoma.

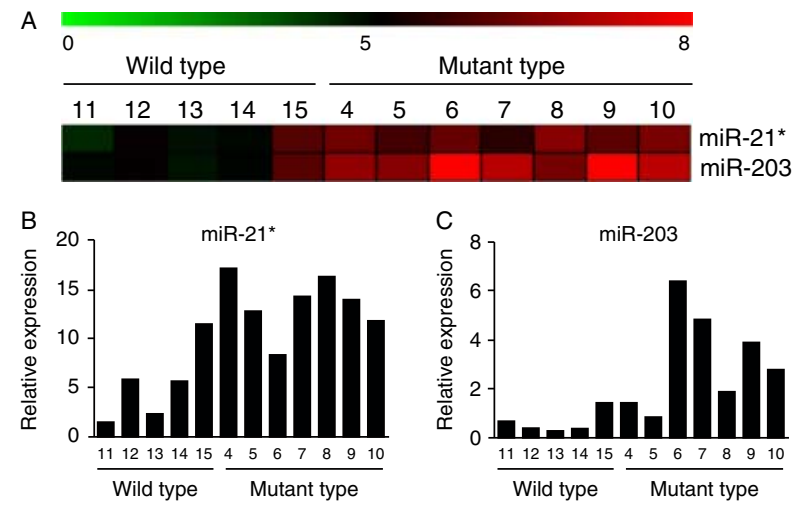

Figure 3 Differential expressions of miR-21* and 203 between $B R A F^{\mathrm{V} 600 \mathrm{E}}$-positive and -negative papillary thyroid carcinomas (PTC). (A, B and C) Expressions of miR-21* and 203 in five $B R A F^{\mathrm{V} 600 \mathrm{E}}$-negative (wild type, Nos 11-15) PTC tissues and seven $B R A F^{-1600 E}$-positive (mutant type, Nos 4-10) PTC tissues using miRNA microarray $(A)$ and real-time quantitative PCR (B and $C$ ). Green bars indicate low expression and red bars indicate high expression. Full colour version of this figure available via http://dx.doi.org/10.1530/EJE-12-1029. 

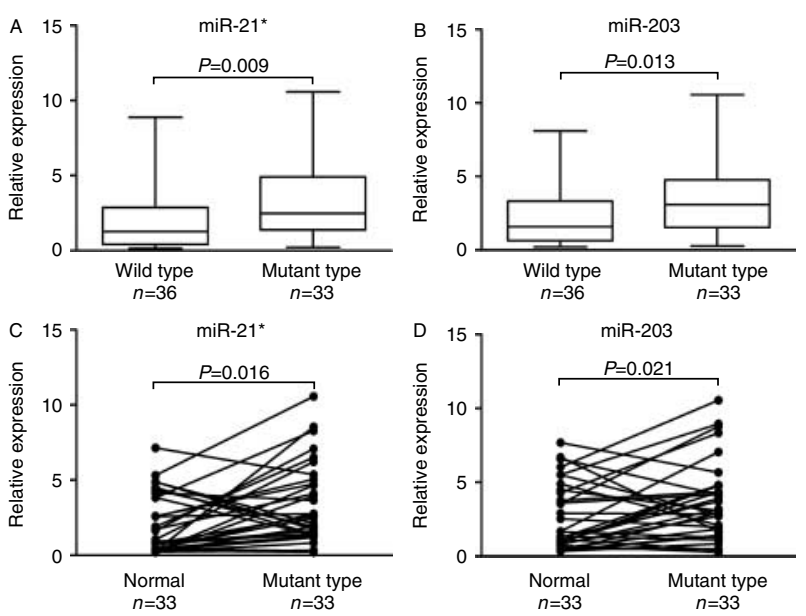

Figure 4 miR-21* and 203 expressions in papillary thyroid carcinomas (PTC) and paracancerous normal thyroid tissues by real-time quantitative PCR. (A and B) The expressions of miR-21* and 203 in 36 BRAF ${ }^{\mathrm{V} 600 \mathrm{E}}$-negative (wild type) PTC tissues and in $33 B R A F^{V 600 E}$-positive (mutant type) PTC tissues; (C and D) the expressions of miR-21* and 203 in $33 B R A F^{V 600 E}$-positive PTC tissues and in 33 associated paracancerous normal thyroid tissues (normal).

It is believed that in thyroid tissues (including normal tissue, benign tumor tissue, and malignant tumor tissue), $B R A F^{\mathrm{V} 600 \mathrm{E}}$ is restricted to PTC and poorly differentiated or anaplastic carcinomas arising from PTC $(30,35,36)$. We detected $B R A F^{\mathrm{V} 600 \mathrm{E}}$ in nearly half of the PTC tissues but in none of the associated paracancerous thyroid tissues, implying that it was a somatic mutation. There is a wide range of reported $(6,7,8,9) B R A F^{\mathrm{V} 600 \mathrm{E}}$ mutation rates, from 29 to $83 \%$; this might be attributable to ethnic heterogeneity and different sample sizes.

Few studies have examined the association between $B R A F^{\mathrm{V} 600 \mathrm{E}}$ and miRNA expression in PTC. On the one hand, $B R A F^{\mathrm{V} 600 \mathrm{E}}$ has an effect on activating BRAFMEK-MAPK signaling pathway (37); on the other hand, miRNAs are posttranscriptional regulators that bind to complementary sequences on target mRNAs, usually resulting in target degradation, translational repression, or gene silencing (15). Cahill et al. (27) investigated the expression of 160 miRNAs in a normal thyroid cell line and two thyroid cell lines containing $B R A F^{\mathrm{V} 600 \mathrm{E}}$; three miRNAs (miR-141, 200a, and 200b) were significantly upregulated and three (miR-127, 130a, and 144) were significantly downregulated in the mutation-carrying cell lines. Nikiforova et al. (18) selected six out of the 158 most highly expressed human miRNAs in PTC tissue and further explored their expressions in 23 PTC tissues (with/without BRAF or RAS gene mutations, or RET/PTC), revealing that five miRNAs (miR-146b, 155, 187, 221, and 222) were differentially expressed among the groups. Sheu et al. (38) assessed the expressions of five selected miRNAs (miR-21, 146b, 181b, 221, and 222) in 56 PTC tissues and concluded that they were not associated with

Table 1 Relationships between clinicopathological characteristics and $B R A F^{\mathrm{V} 600 \mathrm{E}}$ status, miR-21* expression, or miR-203 expression in patients with papillary thyroid carcinoma $(n=69)$.

\begin{tabular}{|c|c|c|c|c|c|c|c|c|c|}
\hline \multirow[b]{2}{*}{ Parameter } & \multicolumn{3}{|c|}{$B R A F^{\mathrm{V} 600 \mathrm{E}}$ status } & \multicolumn{3}{|c|}{ miR-21* } & \multicolumn{3}{|c|}{ miR-203 } \\
\hline & $\begin{array}{c}\text { Mutant type } \\
(\% ; n 1=33 \\
n 2=31)\end{array}$ & $\begin{array}{c}\text { Wild type } \\
(\% ; n 1=36 \\
n 2=35)\end{array}$ & $P$ & $\begin{array}{c}U^{a} \\
(\% ; n 1=45 \\
n 2=43)\end{array}$ & $\begin{array}{c}\text { Down }^{\mathrm{b}} \\
(\% ; n 1=24, \\
n 2=23)\end{array}$ & $P$ & $\begin{array}{c}U^{a} \\
(\% ; n 1=41 \\
n 2=39)\end{array}$ & $\begin{array}{c}\text { Down }^{\mathrm{b}} \\
(\% ; n 1=28 \\
n 2=27)\end{array}$ & $P$ \\
\hline \multicolumn{3}{|l|}{ Age } & \multicolumn{3}{|l|}{0.124} & \multirow[t]{3}{*}{0.408} & & & \multirow[t]{3}{*}{0.436} \\
\hline$\geq 45$ years & $18(55)$ & $13(36)$ & & $23(51)$ & $10(42)$ & & $20(49)$ & $11(39)$ & \\
\hline$<45$ years & $15(45)$ & $23(64)$ & & $22(49)$ & $14(58)$ & & $21(51)$ & $17(61)$ & \\
\hline \multicolumn{3}{|l|}{ Gender } & \multirow[t]{3}{*}{0.828} & & & \multirow[t]{3}{*}{0.935} & & & \multirow[t]{3}{*}{0.863} \\
\hline Male & $6(18)$ & $7(19)$ & & $9(20)$ & $4(17)$ & & $8(20)$ & $5(18)$ & \\
\hline Female & 27 (82) & $29(81)$ & & $36(80)$ & 20 (83) & & $33(80)$ & $23(82)$ & \\
\hline \multicolumn{3}{|l|}{ Number of lesions } & \multirow[t]{3}{*}{0.570} & & & \multirow[t]{3}{*}{0.260} & & & \multirow[t]{3}{*}{0.837} \\
\hline Single & $16(48)$ & $15(42)$ & & $18(40)$ & $13(54)$ & & $20(49)$ & $11(39)$ & \\
\hline Multiple & $17(52)$ & $21(58)$ & & $27(60)$ & $11(46)$ & & $21(51)$ & $17(61)$ & \\
\hline \multicolumn{3}{|l|}{ Lymph node } & \multirow[t]{3}{*}{0.390} & & & \multirow[t]{3}{*}{0.005} & & & \multirow[t]{3}{*}{0.765} \\
\hline No & $14(42)$ & $19(53)$ & & $16(36)$ & $17(71)$ & & $19(46)$ & $14(50)$ & \\
\hline $\mathrm{N} 1$ & $19(58)$ & $17(47)$ & & $29(64)$ & 7 (29) & & $22(54)$ & $14(50)$ & \\
\hline \multicolumn{3}{|l|}{ TNM staging $^{\mathrm{C}}$} & \multirow[t]{3}{*}{0.043} & & & \multirow[t]{3}{*}{0.715} & & & \multirow[t]{3}{*}{0.941} \\
\hline I and II & $17(52)$ & $27(75)$ & & $28(62)$ & $16(67)$ & & $26(63)$ & $18(64)$ & \\
\hline \multirow{2}{*}{\multicolumn{3}{|c|}{ Metastasis or recurrence ${ }^{d^{(40)}}$}} & & 17 (38) & 8 (33) & & $15(37)$ & $10(36)$ & \\
\hline & & & \multirow[t]{3}{*}{0.597} & & & \multirow[t]{3}{*}{1.000} & & & \multirow[t]{3}{*}{1.000} \\
\hline Yes & $2(6)$ & $1(3)$ & & $2(5)$ & $1(4)$ & & $2(5)$ & $1(4)$ & \\
\hline No & $29(94)$ & $34(97)$ & & $41(95)$ & $22(96)$ & & $37(95)$ & $26(96)$ & \\
\hline
\end{tabular}

$n 1$ is the total number of patients available for the data of age at diagnosis, gender, number of lesion, and tumor-node-metastasis (TNM) staging. $n 2$ is the total number of patients available for the data of metastasis or recurrence by 20-45 months of follow-up (median, 32 months; interquartile range, 11 months). ${ }^{a}$ Expression of the miRNA in tumor tissue was higher than that in associated paracancerous normal thyroid tissue.

${ }^{b}$ Expression of the miRNA in tumor tissue was lower than that in associated paracancerous normal thyroid tissue.

CTNM classification is defined according to the American Joint Committee on Cancer (2010).

${ }^{\mathrm{d} C}$ Confirmed by color Doppler ultrasonography or computed tomography during the follow-up period. 
$B R A F^{\mathrm{V} 600 \mathrm{E}}$ status. In our study, we initially identified two differentially expressed miRNAs (miR-21* and 203) between $12 B R A F^{\mathrm{V} 600 \mathrm{E}}$-positive and -negative PTC tissues by both miRNA microarray and qPCR. This was further validated by qPCR in a total of 69 PTC tissues and 33 paracancerous thyroid tissues from $B R A F^{\mathrm{V} 600 \mathrm{E}}$-positive PTC patients. Previous studies have revealed that: activator protein 1 (AP-1) activated the miR-21 transcription in a human promyelocytic cell line (39) and increased the expression of miR-203 in human keratinocytes (40); MAPK signaling pathway had an effect on activating AP-1 (41); and the effect of $B R A F^{\mathrm{V} 600 \mathrm{E}}$ was mediated by the BRAF-MAPK signaling pathway (37). Taken together, we hypothesize that the relationship between $B R A F^{\mathrm{V} 600 \mathrm{E}}$ and over-expression of miR-21* or 203 may be mediated by the MAPK signaling pathway and AP-1, and both miR-21* and 203 have the effect on PTC aggressiveness. However, the absence of differential expressions of miR-21* and 203 between PTC tissues and paracancerous thyroid tissues on the miRNA microarray were probably due to the following: i) the small sample sizes of PTC tissues and paracancerous thyroid tissues for miRNA microarray analysis in the study; ii) the genotypic status (with/ without BRAF or RAS gene mutations, RET/PTC, TRK, etc.) might be different among the 12 PTC tissues; and iii) these two miRNAs might be differentially expressed among different genotypic groups, while this hypothesis is needed to be further tested.

There are discordant findings in the literature in the relationship between $B R A F^{\mathrm{V} 600 \mathrm{E}}$ status and clinicopathological parameters: numerous studies $(8,11,12$, $13,14)$ showed that $B R A F^{\mathrm{V} 600 \mathrm{E}}$ was significantly associated with poor clinicopathological parameters, while a small number of studies $(5,42)$ did not. In this study, we revealed significant relationships between poor clinicopathological features and the following: $B R A F^{\mathrm{V} 600 \mathrm{E}}$ positivity (using $B R A F^{\mathrm{V} 600 \mathrm{E}}$-negative PTC tissues as the control group) and miR-21* overexpression (using paracancerous thyroid tissues as the control group). Interestingly, we also identified a significant association between $B R A F^{\mathrm{V} 600 \mathrm{E}}$ positivity and miR-21* over-expression. The molecular basis of this association should be explored in future studies.

In conclusion, our study has shed new light on the relationships between $B R A F^{\mathrm{V} 600 \mathrm{E}}$ status and miRNA expression, and between differentially expressed miRNA and clinicopathological feature in PTC. Although our findings need to be confirmed in studies of larger sample size, they may lay the foundation for the identification of a potential diagnostic biomarker or prognostic indicator of PTC.

\section{Declaration of interest}

The authors declare that there is no conflict of interest that could be perceived as prejudicing the impartiality of the research reported.

\section{Funding}

This work was supported by National Natural Science Foundation of China (no. 30872522); Natural Science Foundation of Guangdong Province (Key Program; no. 10251008901000004); and Foundation of Young Teachers training of Sun Yat-Sen University (no. 09ykpy46).

\section{References}

1 Xing M. BRAF mutation in thyroid cancer. Endocrine-Related Cancer 200512 245-262. (doi:10.1677/erc.1.0978)

2 Davies L \& Welch HG. Increasing incidence of thyroid cancer in the United States, 1973-2002. Journal of the American Medical Association 2006259 2164-2167. (doi:10.1001/jama. 295.18.2164)

3 Mazzaferri EL \& Jhiang SM. Long-term impact of initial surgical and medical therapy on papillary and follicular thyroid cancer. American Journal of Medicine 199497 418-428. (doi:10.1016/ 0002-9343(94)90321-2)

4 Johnson TL, Lloyd RV, Thompson NW, Beierwaltes WH \& Sisson JC. Prognostic implications of the tall cell variant of papillary thyroid carcinoma. American Journal of Surgical Pathology 198812 22-27. (doi:10.1097/00000478-198801000-00003)

5 Liu RT, Chen YJ, Chou FF, Li CL, Wu WL, Tsai PC, Huang CC \& Cheng JT. No correlation between BRAFV600E mutation and clinicopathological features of papillary thyroid carcinomas in Taiwan. Clinical Endocrinology 200563 461-466. (doi:10.1111/j. 1365-2265.2005.02367.x)

6 Namba H, Nakashima M, Hayashi T, Hayashida N, Maeda S, Rogounovitch TI, Ohtsuru A, Saenko VA, Kanematsu T \& Yamashita $S$. Clinical implication of hot spot BRAF mutation, V599E, in papillary thyroid cancers. Journal of Clinical Endocrinology and Metabolism $2003 \mathbf{8 8}$ 4393-4397. (doi:10.1210/jc. 2003-030305)

7 Kim KH, Kang DW, Kim SH, Seong IO \& Kang DY. Mutations of the BRAF gene in papillary thyroid carcinoma in a Korean population. Yonsei Medical Journal 200445 818-821.

8 Chakraborty A, Narkar A, Mukhopadhyaya R, Kane S, D'Cruz A \& Rajan MG. BRAF V600E mutation in papillary thyroid carcinoma: significant association with node metastases and extra thyroidal invasion. Endocrine Pathology 201223 83-93. (doi:10.1007/ s12022-011-9184-5)

9 Tufano RP, Teixeira GV, Bishop J, Carson KA \& Xing M. BRAF mutation in papillary thyroid cancer and its value in tailoring initial treatment: a systematic review and meta-analysis. Medicine 201291 274-286. (doi:10.1097/MD.0b013e31826a9c71)

10 Nucera C, Porrello A, Antonello ZA, Mekel M, Nehs MA, Giordano TJ, Gerald D, Benjamin LE, Priolo C, Puxeddu E et al. B-Raf(V600E) and thrombospondin-1 promote thyroid cancer progression. PNAS 2010107 10649-10654. (doi:10.1073/pnas. 1004934107)

11 Xing M. BRAF mutation in papillary thyroid cancer: pathogenic role, molecular bases, and clinical implications. Endocrine Reviews 200728 742-762. (doi:10.1210/er.2007-0007)

12 Elisei R, Ugolini C, Viola D, Lupi C, Biagini A, Giannini R, Romei C, Miccoli P, Pinchera A \& Basolo F. BRAF(V600E) mutation and outcome of patients with papillary thyroid carcinoma: a 15-year median follow-up study. Journal of Clinical Endocrinology and Metabolism 200893 3943-3949. (doi:10.1210/jc.2008-0607)

13 Frasca F, Nucera C, Pellegriti G, Gangemi P, Attard M, Stella M, Loda M, Vella V, Giordano C, Trimarchi F et al. BRAF(V600E) mutation and the biology of papillary thyroid cancer. EndocrineRelated Cancer 200815 191-205. (doi:10.1677/ERC-07-0212)

14 Kim SJ, Lee KE, Myong JP, Park JH, Jeon YK, Min HS, Park SY, Jung $\mathrm{KC}$, Koo do $\mathrm{H} \&$ Youn YK. BRAF V600E mutation is associated with tumor aggressiveness in papillary thyroid cancer. World Journal of Surgery 201236 310-317. (doi:10.1007/ s00268-011-1383-1) 
15 Bartel DP. MicroRNAs: genomics, biogenesis, mechanism and function. Cell 2004116 281-297. (doi:10.1016/S00928674(04)00045-5)

16 Dalmay T. MicroRNAs and cancer. Journal of Internal Medicine 2008263 366-375. (doi:10.1111/j.1365-2796.2008.01926.x)

17 Calin GA \& Croce CM. MicroRNA signatures in human cancers. Nature Reviews. Cancer 20066 857-866. (doi:10.1038/nrc1997)

18 Nikiforova MN, Tseng GC, Steward D, Diorio D \& Nikiforov YE. MicroRNA expression profiling of thyroid tumors: biological significance and diagnostic utility. Journal of Clinical Endocrinology and Metabolism 200893 1600-1608. (doi:10.1210/jc.2007-2696)

19 Sheu SY, Grabellus F, Schwertheim S, Worm K, Broecker-Preuss M \& Schmid KW. Differential miRNA expression profiles in variants of papillary thyroid carcinoma and encapsulated follicular thyroid tumours. British Journal of Cancer 2010102 376-382. (doi:10.1038/sj.bjc.6605493)

20 He H, Jazdzewski K, Li W, Liyanarachchi S, Nagy R, Volinia S, Calin GA, Liu CG, Franssila K, Suster $\mathrm{S}$ et al. The role of microRNA genes in papillary thyroid carcinoma. PNAS 2005102 19075-19080. (doi:10.1073/pnas.0509603102)

21 Pallante P, Visone R, Ferracin M, Ferraro A, Berlingieri MT, Troncone G, Chiappetta G, Liu CG, Santoro M, Negrini M et al. MicroRNA deregulation in human thyroid papillary carcinomas. Endocrine-Related Cancer 200613 497-508. (doi:10.1677) erc.1.01209)

22 Tetzlaff MT, Liu A, Xu X, Master SR, Baldwin DA, Tobias JW. Livolsi VA \& Baloch ZW. Differential expression of miRNAs in papillary thyroid carcinoma compared to multinodular goiter using formalin fixed paraffin embedded tissues. Endocrine Pathology 200718 163-173. (doi:10.1007/s12022-007-0023-7)

23 Chen YT, Kitabayashi N, Zhou XK, Fahey TJ III \& Scognamiglio T. MicroRNA analysis as a potential diagnostic tool for papillary thyroid carcinoma. Modern Pathology 200821 1139-1146. (doi:10.1038/modpathol.2008.105)

24 Lassalle S, Hofman V, Ilie M, Bonnetaud C, Puisségur MP, Brest P, Loubatier C, Guevara N. Bordone O, Cardinaud B et al. Can the microRNA signature distinguish between thyroid tumors of uncertain malignant potential and other well-differentiated tumors of the thyroid gland? Endocrine-Related Cancer 201118 579-594. (doi:10.1530/ERC-10-0283)

25 Braun J. Hoang-Vu C, Dralle H \& Hüttelmaier S. Downregulation of microRNAs directs the EMT and invasive potential of anaplastic thyroid carcinomas. Oncogene 201029 4237-4244. (doi:10.1038/onc.2010.169)

26 Kitano M, Rahbari R, Patterson EE, Xiong Y, Prasad NB, Wang Y, Zeiger MA \& Kebebew E. Expression profiling of difficultto-diagnose thyroid histologic subtypes shows distinct expression profiles and identify candidate diagnostic microRNAs. Annals of Surgical Oncology 201118 3443-3452. (doi:10.1245/s10434011-1766-4)

27 Cahill S, Smyth P, Denning K, Flavin R, Li J, Potratz A, Guenther SM, Henfrey R, O'Leary JJ \& Sheils O. Effect of BRAFV600E mutation on transcription and post-transcriptional regulation in a papillary thyroid carcinoma model. Molecular Cancer 20076 21-30. (doi:10.1186/1476-4598-6-21)

28 Li Volsi VA, Albores-Saavedra J, Asa SL, Baloch ZW, SobrinhoSimoes M, Wenig B, DeLellis RA \& Cady B. Papillary carcinoma. In World Health Organization Classification of Tumours: Pathology and Genetics of Tumours of Endocrine Organs, pp 57-66. Eds RA De Lellis, RV Lloyd, PU Heitz \& C Eng, Lyon: IARC Press, 2004.

29 American Joint Committee on Cancer (2010). Thyroid. In AJCC Cancer Staging Manual, edn 7th, pp 87-96. Eds SB Edge, DR Byrd, CC Compton, AG Fritz, FL Greene \& A Trotti, New York: Springer, 2010.

$30 \mathrm{Xu}$ X, Quiros RM, Gattuso P, Ain KB \& Prinz RA. High prevalence of BRAF gene mutation in papillary thyroid carcinomas and thyroid tumor cell lines. Cancer Research 200363 4561-4567.
31 Kitano M, Rahbari R, Patterson EE, Steinberg SM, Prasad NB, Wang Y, Zeiger MA \& Kebebew E. Evaluation of candidate diagnostic microRNAs in thyroid fine-needle aspiration biopsy samples. Thyroid 201222 285-291. (doi:10.1089/thy. 2011.0313)

32 Shen R, Liyanarachchi S, Li W, Wakely PE Jr, Saji M, Huang J, Nagy R, Farrell T, Ringel MD, de la Chapelle A et al. MicroRNA signature in thyroid fine needle aspiration cytology applied to "atypia of undetermined significance" cases. Thyroid 201222 9-16. (doi:10.1089/thy.2011.0081)

33 Keutgen XM, Filicori F, Crowley MJ, Wang Y, Scognamiglio T, Hoda R, Buitrago D, Cooper D, Zeiger MA, Zarnegar R et al. A panel of four miRNAs accurately differentiates malignant from benign indeterminate thyroid lesions on fine needle aspiration. Clinical Cancer Research 201218 2032-2038. (doi:10.1158/1078-0432. CCR-11-2487)

34 Davies H, Bignell GR, Cox C, Stephens P, Edkins S, Clegg S, Teague J. Woffendin H, Garnett MJ. Bottomley Wet al. Mutations of the BRAF gene in human cancer. Nature 2002417 949-954. (doi:10.1038/nature00766)

35 Kim SK, Kim DL, Han HS, Kim WS, Kim SJ, Moon WJ, Oh SY \& Hwang TS. Pyrosequencing analysis for detection of a BRAFV600E mutation in an FNAB specimen of thyroid nodules. Diagnostic Molecular Pathology 200817 118-125. (doi:10.1097/ PDM.0b013e31815d059d)

36 Nikiforova MN, Kimura ET, Gandhi M, Biddinger PW, Knauf JA, Basolo F, Zhu Z, Giannini R, Salvatore G, Fusco A et al. BRAF mutations in thyroid tumors are restricted to papillary carcinomas and anaplastic or poorly differentiated carcinomas arising from papillary carcinomas. Journal of Clinical Endocrinology and Metabolism 2003 88 5399-5404. (doi:10.1210/jc.2003-030838)

37 Heidorn SJ, Milagre C, Whittaker S, Nourry A, Niculescu-Duvas I, Dhomen N, Hussain J, Reis-Filho JS, Springer CJ, Pritchard C et al. Kinase-dead BRAF oncogenic RAS cooperate to drive tumor progression through CRAF. Cell 2010140 209-221. (doi:10.1016/j.cell.2009.12.040)

38 Sheu SY, Grabellus F, Schwertheim S, Handke S, Worm K \& Schmid KW. Lack of correlation between BRAF V600E mutational status and the expression profile of a distinct set of miRNAs in papillary thyroid carcinoma. Hormone and Metabolic Research 200941 482-487. (doi:10.1055/s-0029-1215558)

39 Fujita S, Ito T, Mizutani T, Minoguchi S, Yamamichi N, Sakurai K \& Iba H. miR-21 gene expression triggered by AP-1 is sustained through a double-negative feedback mechanism. Journal of Molecular Biology 2008378 492-504. (doi:10.1016/j.jmb.2008.03.015)

40 Sonkoly E, Wei T, Pavez Loriè E, Suzuki H, Kato M, Törmä H, Ståhle M \& Pivarcsi A. Protein kinase C-dependent upregulation of miR-203 induces the differentiation of human keratinocytes. Journal of Investigative Dermatology 2010130 124-134. (doi:10.1038/jid.2009.294)

41 Domenzain-Reyna C, Hernández D, Miquel-Serra L, Docampo MJ, Badenas C, Fabra A \& Bassols A. Structure and regulation of the versican promoter: the versican promoter is regulated by AP-1 and TCF transcription factors in invasive human melanoma cells. Journal of Biological Chemistry $2009 \quad \mathbf{2 8 4}$ 12306-12317. (doi:10.1074/jbc.M807108200)

42 Kim TY, Kim WB, Song JY, Rhee YS, Gong G, Cho YM, Kim SY, Kim SC, Hong SJ \& Shong YK. The BRAF mutation is not associated with poor prognostic factors in Korean patients with conventional papillary thyroid microcarcinoma. Clinical Endocrinology 200563 588-593. (doi:10.1111/j.1365-2265.2005.02389.x)

Received 23 November 2012

Revised version received 8 February 2013

Accepted 12 February 2013 